\title{
The effects of adrenergic $\beta$-blockade with oxprenolol on peripheral metabolism
}

\author{
A. C. Asmal \\ M.D., F.C.P., M.R.C.P. \\ A. J. Coleman \\ M.B., B.S., F.F.A.R.C.S. \\ W. P. LEARY
M.Sc., M.B., B.Ch., D.Phil., M.R.C.P., F.C.P. \\ Department of Clinical and Experimental Pharmacology, Faculty of Medicine, University of \\ Natal, Durban, South Africa
}

\begin{abstract}
Summary
Peripheral metabolism was studied with the forearm technique in six fasting normal subjects before and after oxprenolol administration. With the forearm technique the product of blood flow and arteriovenous differences is a measure of substrate uptake or release, and, therefore, an index of metabolism. Blood flow was measured with venous occlusion plethysmography, and arterial and venous samples obtained through indwelling catheters in the radial artery and deep forearm vein.

Oxprenolol administration influenced both peripheral flow and the basal pattern of substrate exchange. Before oxprenolol blockade a net uptake of glucose, triglycerides, and FFA, and a net release of glycerol were recorded across the forearm. After oxprenolol blockade there was a marked reduction in triglyceride uptake, with augmentation of glucose uptake and inhibition of lipolysis.
\end{abstract}

\section{Introduction}

Adrenergic $\beta$-receptor activity regulates a variety of metabolic events both centrally and peripherally (Havel, 1965; Brodie, Maickel and Stern, 1965; Himms-Hagen, 1970; Imura et al., 1971; Fain, 1973). Such events have been investigated by one of two basic approaches-infusions of catecholamines or $\beta$-adrenoreceptor blocking drugs followed by measurements of plasma levels of insulin, growth hormone, FFA, and glucose (lmura et al., 1971; Lundholm, Mohme-Lundholm and Svedmyr, 1968), or by the use of in vitro muscle and adipose tissue preparations (Fain, 1973). The in vivo techniques measure the sum total of metabolic events, both primary, due to direct action on the $\beta$-receptor, and secondary, due to initiation of counter-regulatory mechanisms elsewhere (Brodie et al., 1965). In vitro studies have the advantage of providing information

Correspondence: Dr A. C. Asmal, Department of Clinical and Experimental Pharmacology, Box 39 Congella, Natal, South Africa. on $\beta$-receptor activity of a more direct nature, e.g. effects on glucose utilization and lipolysis. A shortcoming of in vitro data is that they may not reflect with accuracy events as they occur in the intact organism.

The human forearm technique has been extensively utilized in the study of peripheral metabolism (Butterfield and Holling, 1959; Rabinowitz and Zierler, 1962; Wahren, 1966; Posefsky, Felig and Tobin, 1969; Zampa et al., 1967; Asmal, 1972). The basis of the technique is the simultaneous measurement of blood flow and arteriovenous differences, the product of which is a measure of peripheral metabolism. It has the virtue of directly measuring metabolic events, albeit only in the periphery, and helps to bridge the gap between data derived from physiological studies in whole man, and those obtained from biochemical studies in the test-tube (Asmal, 1972). Previous studies have reported on the role of insulin in peripheral glucose utilization (Asmal et al., 1971a; Whichelow et al., 1971; Karamanos et al., 1971) as well as on the complex interrelationships of hormones and substrates (Asmal et al., 1971b; Asmal, 1972). More recently the observation of triglyceride release from peripheral tissues into the circulation in diabetes has raised the possibility that this may contribute to the hypertriglyceridaemia of diabetes (Asmal et al., 1973).

This study was designed to investigate the effects of $\beta$-receptor blockade on the peripheral metabolism of glucose and lipids. This paper reports our findings in a group of normal volunteers.

\section{Material and methods}

Experimental

The nature of the study was explained to all six subjects (five males, and one female), who gave informed consent. The age range was 25-35 years, and weight was within $10 \%$ of desirable weight (Scientific Tables, Documenta Geigy, 1962). There was no history of diabetes or other disorder of metabolism. 
All investigations were performed in a metabolic laboratory after an overnight fast. Subjects lay comfortably in a horizontal position for the duration of the study. Under aseptic conditions and local analgesia a 'Medicut' 18 gauge cannula was introduced centripetally into the radial artery of one arm, and a 16 gauge 'Ezi-catheter' inserted centrifugally into a deep forearm vein of the contralateral arm. A silastic strain gauge was applied around the circumference of the upper third of the latter forearm, and connected to a plethysmograph preamplifier (Parks Electronics Model 270) itself linked to a potentiometric recorder. Cuffs for instantaneous pressure application were placed at the wrist (pressure $200 \mathrm{mmHg}$ ) and upper arm (pressure $60 \mathrm{mmHg}$ ) and when completed, the subjects were allowed to become 'basal'. The arterial and venous cannulae were kept patent with slow infusions of $0.9 \%$ saline containing no heparin.

With the subjects in a basal state, the wrist cuff was inflated to a pressure of $200 \mathrm{mmHg}$ and kept at this level until the completion of the study-about $20 \mathrm{~min}$. Two sets of control flow measurements and blood samples, separated by $5 \mathrm{~min}$, were first taken as follows: several flows were measured over a 2-min period, blood was then taken simultaneously and uniformly from the artery and vein over a 1-min period and concomitant flows measured; after $2 \mathrm{~min}$ the second set of control values were taken. After this, therapeutically recommended doses of oxprenolol, ranging from 1 to $4 \mathrm{mg}$ were injected slowly into an indwelling needle. At intervals of 8-10 min after the injection, two further sets of blood flow measurements and blood samples were taken.

For the calculation of uptake, mean blood flows taken immediately before the sampling period were utilized in preference to those obtained concomitantly with the sampling. This was because the sampling procedure tended to produce artifacts in the flow configuration and made attempts to measure flow accurately difficult. Although this may have introduced a systematic error in the measurements, the magnitude of this could not be of much consequence because of the steady state situation prevailing. Other workers have also had recourse to this ploy (Jackson et al., 1973).

\section{Chemical}

Plasma glucose was measured by the automated ferricyanide technique (modified from Hoffman, 1937), FFA by Duncombe's method (1964), and glycerol and triglycerides enzymatically (Boehringer method, 1972). Standard statistical methods were used (Bradford-Hill, 1968). The standard deviation (s.d.) of replicate analyses was $3.31,0.013$, and 0.097 for triglycerides, FFA, and glycerol respectively. The formula used was s.d. $=\left(\Sigma d^{2} / 2 n\right)^{\frac{1}{2}}$, where $d=$ difference between duplicate samples, and $n=$ number of duplicate pairs which were, respectively, 48, 24, and 48 for triglycerides, FFA, and glycerol.

\section{Results}

\section{Pulse rate}

In the recommended therapeutic dosage range (1-4 $\mathrm{mg}$ ) no significant change, either in the mean pulse rates or in paired observations (Table 1), was noted.

\section{Plasma flow}

Although there was no significant difference in the mean plasma flows before and after blockade ( 2.69 $\mathrm{ml} / 100 \mathrm{ml} / \mathrm{min}$ and $2.36 \mathrm{ml} / 100 \mathrm{ml} / \mathrm{min}$ respectively), comparison of paired values in individual subjects revealed significant changes (Table $1, P<0.01$ ).

\section{Plasma concentration}

The plasma arterial and venous concentrations of substrates before and after blockade were as follows. The differences before and after oxprenolol administration are not significant. Blockade is accompanied by an increase in the arterial values of glucose (from 93 to $98 \mathrm{mg} / 100 \mathrm{ml}$ ) and glycerol (from 0.84 to 0.97 $\mathrm{mg} / 100 \mathrm{ml}$ ) and decrease in the arterial levels of FFA (from 0.43 to $0.37 \mathrm{mmol} / \mathrm{l}$ ) and triglycerides (from 117 to $115 \mathrm{mg} / 100 \mathrm{ml}$ ). The effects of blockade on the plasma venous concentrations are less pronounced-the glucose and FFA levels remain more or less unchanged while those of glycerol show a slight fall (from 0.95 to $0.90 \mathrm{mg} / 100 \mathrm{ml}$ ) and those of triglyceride a rise $(108$ to $114 \mathrm{mg} / 100 \mathrm{ml})$.

\section{Arteriovenous differences (Table 1)}

In every subject blockade is accompanied by a reduction in the magnitude of the arteriovenous differences of triglycerides $(P<0.025)$, and an increase in the magnitude of the exchange of glucose $(P<0.01)$. The reduction in FFA, and increase in glycerol arteriovenous differences on blockade are not significant changes.

\section{Peripheral exchange (Fig. 1)}

In the control period there is net uptake of triglycerides, FFA and glucose, and net release of glycerol. On oxprenolol administration, triglyceride uptake falls from a value of $267 \mathrm{nmol} / 100 \mathrm{ml} / \mathrm{min}$ to $16 \mathrm{nmol} / 100 \mathrm{ml} / \mathrm{min}$. The fall is significant $(P<$ $0.025)$. There is also an attenuation of FFA uptake $(P$ n.s.). In contrast net glucose uptake is augmented from low basal levels of $510 \mathrm{nmol} 100 \mathrm{ml} / \mathrm{min}$, to $990 \mathrm{nmol} / 100 \mathrm{ml} / \mathrm{min}$ on adrenergic blockade. Glycerol release is suppressed by oxyprenolol as shown by the reduction in plasma venous concentration. The stimulation of peripheral glycerol uptake on blockade is an unexpected finding. 


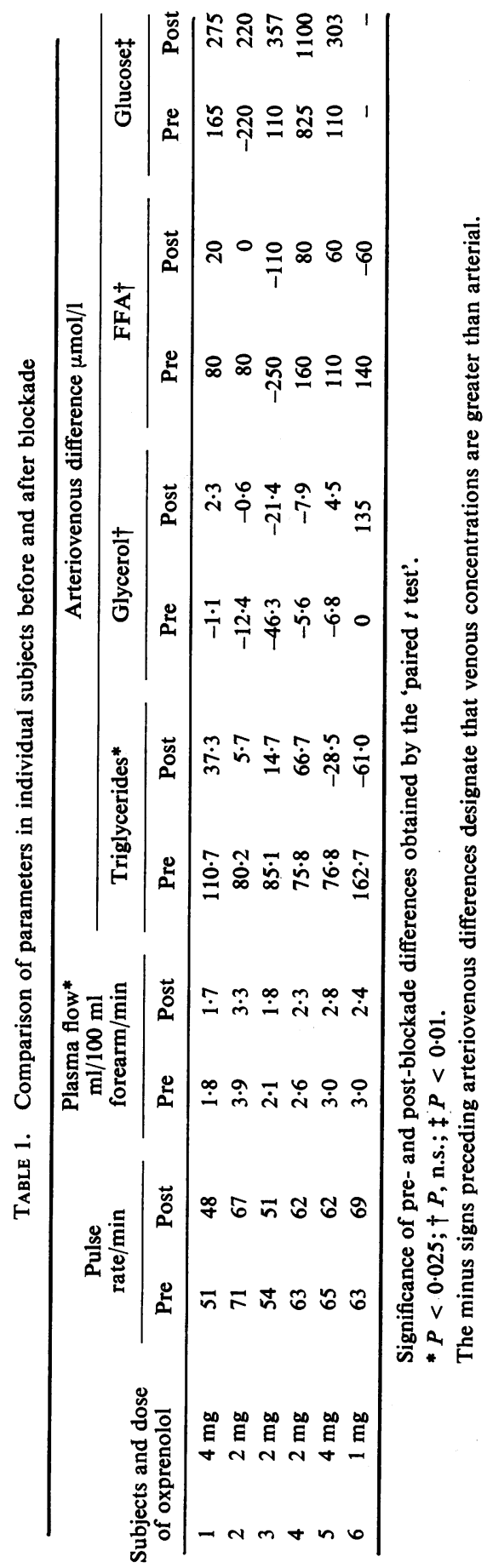



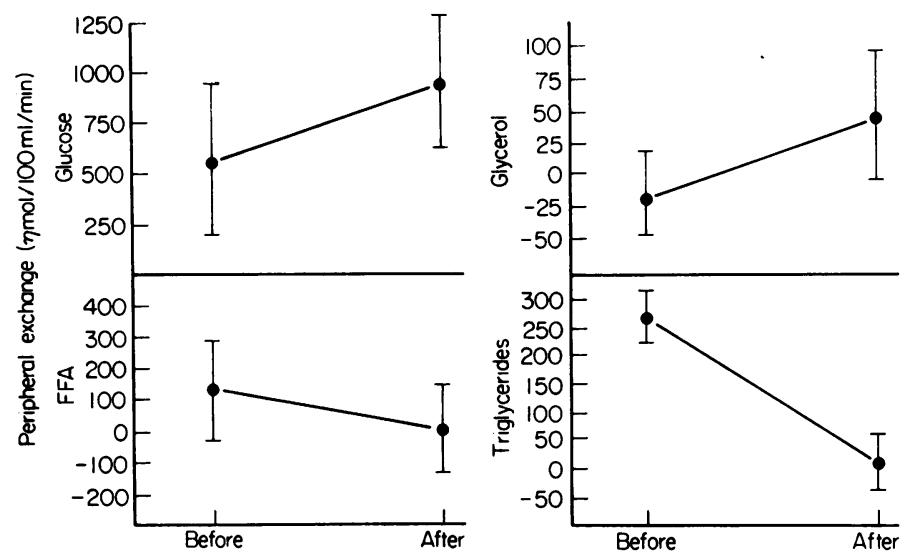

Fig. 1. The effects of oxprenolol blockade on the peripheral exchanges (mean \pm s.e.) of glucose ( $P$ n.s.), FFA $(P$ n.s. $)$, glycerol $(P$ n.s. $)$ and triglycerides $(P<0.025)$.

\section{Discussion}

The metabolic events described represent the sum total of biochemical changes in all tissues of the forearm-of which muscle and adipose tissue predominate. A limitation of the forearm technique is that it cannot discriminate between metabolic activity in these tissues. Within the scope of the forearm technique the term uptake may denote one of several events:

(1) An adsorption of substrate molecules to the capillary endothelium. This may occur during the uptake of, e.g. triglycerides which are hydrolysed by lipoprotein lipase on the endothelial surface.

(2) A sequestration of substrate in the interstitial space where molecules may be in equilibrium between the plasma and cell, e.g. FFA.

(3) An attachment of the substrate to the cell membrane, e.g. glucose before active transport.

(4) Intracellular metabolism which may represent either oxidation or storage as glycogen or triglycerides.

Both the adipocyte and the blood vessels of fat tissue have a rich sympathetic innervation (Havel, 1965; Brodie et al., 1965; Fain, 1973). Metabolic function of adipose tissue is considered to be under tonic sympathetic control. This is mediated via $\beta_{1}$ receptors (Fain, 1973), which also respond to blood stream-borne catecholamines. $\beta$-receptors also modulate metabolic activity in muscle.

The metabolic events occurring in the forearm before blockade show a net uptake of glucose, FFA and triglycerides from the circulation and release of glycerol into it. FFA are preferentially oxidized by muscle in the basal state (Andres, Cader and Zierler, 1956). The distribution of glucose may be shared between adipose tissue where it promotes reesterification and muscle where it is oxidized. The triglycerides restore depleted stores in both adipose tissue and muscle. Muscle has a higher concentration of the enzyme lipoprotein lipase in the basal state (Robinson, 1970). If uptake of triglycerides were dependent solely on luminal hydrolysis its flux into muscle would be greater than in adipose tissue. Prior hydrolysis may not be a prerequisite for triglyceride uptake.

Glycerol release results from both luminal hydrolysis and the lipolysis of stored intracellular triglycerides. Both the enzymes responsible for lipolysis-lipoprotein lipase, and triglyceride lipase-are controlled by the level of cyclic AMP which has reciprocal effects on the two enzymes (Tepperman and Tepperman, 1970). The level of cyclic AMP activity itself is regulated by $\beta$-receptor control.

On oxprenolol blockade FFA and triglyceride uptake is reduced. The reduction in triglyceride uptake may be due either to a direct inhibition of net transfer of unhydrolysed triglycerides, or secondary to a suppression of lipolysis on the capillary endothelium. One effect of this attenuated removal would be the observed elevation in venous plasma. The cessation of peripheral glycerol release is consistent with the suppression of lipolysis both on the endothelium and in the adipocyte. Of greater interest is the finding of net glycerol uptake in the periphery. Evidence for this has been found previously in the periphery (Häggendal et al., 1967), and also across the myocardium (Carlson et al., 1973), and is in keeping with the demonstration of glycerokinase activity in peripheral tissues (Robinson and Newsholme, 1967). The augmentation of peripheral glucose uptake on adrenergic blockade is consistent with the known action of catecholamines in reducing muscle glucose utilization (Lundholm et al., 1968). The rise in arterial glucose concentration is contrary to the 
fall expected from direct blockade of hepatic glycogenolysis. It may be due in part to a suppression of insulin secretion by $\beta$-blockade (Porte, 1967), thereby removing, perhaps, the more potent inhibitory effect on glycogenolysis. In part it may reflect an absence of direct influence on hepatic glycogenolysis, an action noted with pronetholol (Pilkington, 1962).

Over the limited period of observation $\beta$-blockade has been demonstrated to transform the metabolic traffic of substrates. There appears to be a preferential increase in glucose over lipid utilization. Whether these changes are transitory, or contribute significantly to quantitative aspects of energy utilization cannot be assessed on the basis of the present study. These preliminary findings underline the need to examine the situation in different categories of patients, and in greater depth to measure other substrate exchanges. Certainly if $\beta$-blockers are found to reduce fat and promote carbohydrate oxidation the implications from a long term point of view may be profound.

\section{Acknowledgments}

We thank Mr C. J. Lockett and Miss L. Bees for invaluable technical assistance, Mrs Y. Potgieter for typing the manuscript and Professor S. M. Joubert for facilities. Dr J. Swerdlow of Ciba-Geigy provided the oxprenolol for injection.

\section{References}

Andres, R., Cader, G. \& Zierler, K.L. (1956) The quantitatively minor role of carbohydrate in oxidative metabolism by skeletal muscle in intact man. Journal of Clinical Investigation, 35, 671 .

Asmal, A.C. (1972) The peripheral metabolism of hormones and substrates. M.D. Thesis, University of London.

Asmal, A.C., Butterfield, W.J.H., Karamanos, B., Cox, B.D. \& WHICHELOW, M.J. (1971a) The peripheral uptake of glucose and endogenous insulin with particular reference to obesity, weight reduction and the problem of insulin sensitivity. Postgraduate Medical Journal, June Suppl., 407.

Asmal, A.C., Butterfield, W.J.H., Karamanos, B. \& Whichelow, M.J. (1971b) The relative importance of arterial concentrations and tissue uptakes (of hormones and substrates) in the regulation of peripheral metabolism. Diabetologia, 7, 468.

Asmal, A.C., Butterfield, W.J.H., Karamanos, B. \& WhICHELOW, M.J. (1973) The peripheral metabolism of triglycerides. 8th Congress of the International Diabetes Federation, Brussels, July, 1973.

Boehringer Test HaNdbook (1972) The Boehringer Corporation (London) Ltd.

Bradford-Hill, A. (1968) The Principles of Medical Statistics. Lancet Press.

Brodie, B.B., Maickel, R.P. \& Stern, D.N. (1965) In: Handbook of Physiology, Section 5: Adipose Tissue (Ed. by A. E. Renold and G. F. Cahill Jr). American Physiological Society: Washington, D.C.
Butterfield, W.J.H. \& Holling, H.E. (1959) Peripheral glucose metabolism in fasting control subjects and diabetic patients. Clinical Science, 18, 149.

Carlson, L.A., Kaijser, L., Rossner, S. \& Wahlqvist, M.L. (1973) Myocardial metabolism of exogenous triglyceride in resting man. Acta medica scandinavica, 193, 233.

Duncombe, W.G. (1964) The colorimetric microdetermination of FFA. Clinica chimica acta, 9, 122.

FAIN, J.N. (1973) Biochemical aspects of drug and hormone action on adipose tissue. Pharmacological Reviews, 25, 67.

Häggendal, E., Kerstel, J., Steen, B. \& Svandbörg, A. (1967) Uptake of oxygen and substrates in the human skeletal muscle. Acta medica scandinavica, 181, 417.

Havel, R.J. (1965) In: Handbook of Physiology, Section 5: Adipose Tissue (Ed. by A. E. Renold and G. F. Cahill Jr). American Physiological Society, Washington, D.C.

Himms-Hagen, J. (1970) Adrenergic receptors for metabolic response in adipose tissue. Federation Proceedings. Federation of American Societies for Experimental Biology, 29, 1388.

ImURA, H., Kato, Y., IKedA, M., MoRimoto, M. \& YamaWATA, M. (1971) Effect of adrenergic blocking or stimulating agents on plasma growth hormone, insulin and FFA in man. Journal of Clinical Investigation, 50, 1069.

Jackson, R.L., Peters, N., Advani, V., Perry, G., Rogers, J., Brough, W.H. \& Pickington, T.R.E. (1973) Forearm glucose uptake during the oral glucose tolerance test. Diabetes, 22, 442.

Karamanos, B., Butterfield W.J.H., Asmal, A.C. \& Whichelow, M.J. (1971) Peripheral insulin and glucose utilization in tolbutamide-induced hypoglycaemia. Diabetologia, 7, 486.

Lundholm, L., Mohme-Lundholm, E. \& Svedvyr, N. (1968) In: Biological Basis of Medicine (Ed. by E. E. Bittar and N. Bittar), vol. 2. Academic Press: London.

Pilkington, T.R.E. (1962) Effect of adrenergic blockade on? glucose and fatty acid mobilization in man. Lancet, ii, 316.

PORTE, D. (1967) Beta adrenergic stimulation of insulin release in man. Diabetes, 16, 150.

Posefsky, T., Felig, P. \& Tobins, J.D. (1969) Amino acid balance across the tissues of the forearm. Journal of Clinical Investigation, 58, 2273.

Rabinowitz, D. \& Zierler, K.L. (1962) Forearm metabolism in obesity. Journal of Clinical Investigation, 41, 2173.

RoBINSON, D.S. (1970) In: Comprehensive Biochemistry (Ed. by M. Florkin and E. H. Stotz). Elsevier: Amsterdam.

Robinson, J. \& Newsholme, E.A. (1967) Glycerol kinase activities in rat heart and adipose tissue. Biochemical Journal, 104, 2c.

TePPERMAN, J. \& TePPERMAN, H.M. (1970) Gluconeogenesis, lipogenesis and the sherringtonian metaphor. Federation Proceedings. Federation of American Societies for Experimental Biology, 29, 1284.

WAHREN, J. (1966) Quantitative aspects of blood flow and oxygen uptake in the human forearm during rhythmic exercise. Acta phsyiologica scandinavica, 67, Suppl. 269.

Whichelow, M.J., Butterfield, W.J.H., Asmal, A.C. \& Karamanos, B. (1971) Peripheral metabolism in obesity. Seminar on Fenfluramine, 1971, Nassau, Bahamas.

Zampa, G.A., Altilia, F., Brachetti, D., Gemiani, G.D., Borgatti, E. \& Odifreddi, M.T. (1967) Studies on peripheral glucose metabolism. Diabetologia, 3, 35. 